POLISH POLITICAL SCIENCE YEARBOOK

2015, Vol. 44

PL ISSN 0208-7375

DOI: $10.15804 /$ ppsy2015017

Bożena Wroniszewska*

\title{
LEGAL AND POLITICAL DETERMINANTS OF IMPLEMENTATION OF THE PRINCIPLE OF SUBSIDIARITY IN THE FEDERAL REPUBLIC OF GERMANY
}

\begin{abstract}
It is not surprising that subsidiarity is very often discussed with autonomy and federation (equally multidimensional concepts, similarly discussed in science). It is clearly evident taking into account, for example, results of analysis of the key words (tags) in scientific publications. The European Union has significantly contributed in popularizing of the concept so it is no surprise that strongly linked with EU's problems has become a central point of the discussion of its organizational structure and internal relationships between forming elements. It is difficult to imagine analysis of the conditions for implementing of subsidiarity in Germany without prior presentation of the state political system's solutions. Studying the structure and functioning of public administration enables to identify the place and role of the local government, to measure degree of independence of the local authority as a central point of discussion in relation to the subsidiarity.

Keywords: political determinants, subsidiarity, Federal Republic of Germany, European Union, political organizational system, Federal States, legislative, principle of subsidiarity
\end{abstract}

\footnotetext{
* University of Opole.
} 


\section{INTRODUCTION}

Undoubtedly the principle of subsidiarity can be classified as one of the most popular scientific term being discussed by scholars for several decades. There are only a few concepts able to compete successfully with subsidiarity in this regard. This is clearly confirmed by a review of the literature related to the topic, even if it is only a general overview. In the early 90's of the twentieth century Ken Endo at the University of Hokkaido, undisputed authority in the field of subsidiarity, pointed out that there is a deficit in the publications, monographs in particular (Endo, 1994, p. 650). Since then, however, some enormous changes have occurred and today it seems that the term is so pervasive, that it is possible to create separate libraries only for studies related to the issue of subsidiarity.

The European Union has significantly contributed in popularizing of the concept so it is no surprise that strongly linked with EU's problems has become a central point of the discussion of its organizational structure and internal relationships between forming elements. However, it is not just a concept or an organizational principle but a legal norm that was expressed in the subsequent, starting from Maastricht (TEU, 1992), European treaties. As a result of EU's efforts subsidiarity has appeared in the political dictionary, has taken root and well established in the public awareness. What is more, the use of this term has become quite fashionable and is an integral part of the European language (Endo, 1994, p. 650). Moreover, the interest in the issues, a permanent presence in the scientific discussion and the ensuing abundance of literature on the subject are the results of the complexity of subsidiarity, its essence and the role it has to meet. Actually there is a lack of compliance with respect to any matter relating to the subsidiarity, with the meaning of the term starting, which, as stated by Aaron Martin, is at least „vague” (Martin, 2010, p. 4), the typology, at its merits ending. Furthermore, the discussion in this regard involves representatives from many fields of science. This interdisciplinary approach, lack of a single theoretical base and flexibility in the interpretation of subsidiarity imply question about its application in practice.

Subsidiarity, generally speaking, as its name suggests, equips larger communities with only a supporting, secondary one role in relations 
with individuals or smaller groups created by them. The latter should independently, without any interference from larger groups, to be authorized to decide on matters regarding them, unless in some way it is beyond their capabilities. In this case, the intervention is not only justified, but even morally ordered (a stronger one supports a weaker one) However, this does not mean any substitution in completing the task, but only support. Subsidiarity, therefore, limits the scope of interference of larger organizations and imposes a duty to support them if necessary at the same time.

In political science, and this point of view has accepted in this article, where the power is the central point of all considerations, the principle of subsidiarity must be understood as the division of competences providing for the authorities located at the lowest level in the hierarchy (citizens and their social associations, communities), in the first place, the right to participate in the exercise of power, decision-making processes regarding their own affairs. Here the role of the state is the secondary one, limited to the cases of where local authorities are not able to meet the needs of (local) community on their own, executing some specified tasks (Spiering, Albrecht, 1990, p. 339). It is not allowed to take these tasks over by the State through arbitrary decision, is only permitted (and even obligated) to provide an adequate support for its subunits. Thus, according to Anna Marie Pållson, subsidiarity is an answer to the question about the best as possible way to organize society through the division of competences in public administration clearly defining both organizational bodies and actions required in specific areas (Pållson, 2013, p. 6). Undoubtedly, the vertical dimension of subsidiarity (and its specifically dual nature) is disclosed here. It regulates the relations between elements of the public administration, or more strictly, those between the competent central authority and lower - local and regional - authorities. „Locality” is therefore seen as a focal and starting point in the analysis of subsidiarity, because the power to act takes direction "from the bottom to the top". Therefore, should be considered that the functioning of the local government and rather the quality of its activity (the extent to which citizens are able to attend self - consciously in decision-making process on matters which affect them) is the clearest measure of implementation of the principle of subsidiarity. 
Taking into account the previous findings, there is no doubt that the implementation of subsidiarity requires some specific structural determinants. If it is a question of decision - making process located as close to citizens as possible, it must be associated with a certain degree of autonomy for the lowest located authorities (subunits), and (because of the division of competences) some degree of decentralization should be expected.

Thus it is not surprising that subsidiarity is very often discussed with autonomy and federation (equally multidimensional concepts, similarly discussed in science). It is clearly evident taking into account, for example, results of analysis of the key words (tags) in scientific publications. However, not only there, because it should be noted that the compatibility of concepts may be indicated by interest of subsidiarity in the European Union with regard to its constitutional nature (which in the course of time more and more has been perceived as having the characteristics of federalism) (Schout, Wolff, 2010) and the division of competencies between the EU authorities and Member States. Mutual relations between subsidiarity, autonomy and federalism are not discussed thoroughly in this article. The views on this issue differ significantly - some of them have identified subsidiarity with autonomy, other perceive it as a „federal principle" and supreme organizational principle of the federal state, its base (Boka, 2014, p. 13), or treat as a „soul of federation” (Bednar, 2014), „another form” (subcategory) of federalism (Blank, 2009, p. 522, 533) considering concepts to be complementary (Demirci, 2003, p. 26) or to be wholly different (Drèze, 2009, p. 10; Martin, 2010, p. 6; Blank, 2009, p. 511). It is worth noting that the discussion in this matter although nowadays strongly linked with the European Union, its beginnings reach far back into the past - ancient times (its elements can be found in Aristotle) (Endo, 2001 ), or $17^{\text {th }}$ century, especially in the thoughts of Johannes Althusius (Chmielewska, 2012). It seems that most of the scientists believe that the federation as a "unity in diversity”, though heterogeneous in its typology and dynamic phenomenon (Swenden, 2006), and unlike as in relation to subsidiarity, not necessarily requires the primacy for the lower levels in distribution of power (Demirci, 2003, p. 26), is a political system not only offering the best conditions for the efficient, full as possible implementation of subsidiarity and, subsidiarity, in turn, not only supports managing 
of diversified structures, but also enhances its adaptability necessary in permanently changing environment (Bednar, 2014, p. 231).

Both, the subsidiarity and federalism are vague, flexible in interpretation ideas but, according to $\mathrm{M}$. Gierycz, the first one definitely raised far less controversy (Gierycz, 2009, p. 38). This is the reason why subsidiarity has been accepted by the Member States, even those ones, where all federal tendencies are firmly rejected (United Kingdom) (Watts, 2003, p. 162). Subsidiarity is considered as a "crafty circumvention of the "f" word" (Martin, 2010, p. 4) or ,the Trojan horse of federalists” (Endo, 1994, p. 1-2).

Apart from theoretical considerations and political castling in the European Union, the fact is that the principle of subsidiarity has found its place in the EU legal system and thus all Member States also made commitment to adopt subsidiarity and implement in their countries.

They differ in the terms of their political systems, but some of them are federations or countries where the elements characterizing this political system are quite strong. The Federal Republic of Germany is the best example. In this country, in the frame of Federal States (Länder), equipped with a large (but not full) sovereignty, operate equally autonomous local governments. The Federation only retains the competences necessary to maintain the sovereignty and unity of the State, essentially the power is held by Länder. Subsidiarity has been included in the Basic Law of the Federal Republic of Germany, but the provision actually refers to the European Union. In addition, federal and federal states' competencies have been specifically listed in the document.

The purpose of this article is to examine the determinants of implementation of the principle of subsidiarity but not its practical aspects because the analysis would exceed acceptable volume of this publication. Germany, for many reasons, from the very beginning, together with the United Kingdom, particularly promoted the introduction of the principle of subsidiarity to EU's legal system and its practical application in Member States. In addition, the Federal Republic of Germany is considered as one of the best - functioning States. It does seem like the question about determinants of implementation of subsidiarity in that country is quite reasonable and adequate. 


\section{POLITICAL ORGANIZATIONAL SYSTEM IN THE FEDERAL REPUBLIC OF GERMANY}

It is difficult to imagine analysis of the conditions for implementing of subsidiarity in Germany without prior presentation of the state political system's solutions. Studying the structure and functioning of public administration enables to identify the place and role of the local government, to measure degree of independence of the local authority as a central point of discussion in relation to the subsidiarity.

According to its name, the Federal Republic of Germany is a federation with a parliamentary cabinet system with particularly distinct position of the Federal Chancellor (Bundeskanzler) as a head of the Federal Government (Bundesregierung) (Sulowski, Wojtaszczyk, 2005). The State functioning is based on the act of the highest rank in the legal system, the Basic Law (Grundgesetz für Bundesrepublik Deutschland - abbr. GG) of 1949 (The Basic Law..., 1949).

According to the main system's characteristics of the federal state, the Basic Law is a formal (is written) and rigid, which means that the change of regulations is more difficult in comparison with the other laws, because requires the implementation of a special procedure (eligible conditions) in order to protect the fundamental principles of the State (Demirci, 2003, p. 26).

The first and most important is the principle of the federal State already articulated in the preamble to the Basic Law by mentioning the States ((Bundes)länder) which form the Federation ,in free self - determination". However, the constitution in art. 20(1) describes Germany directly as „democratic and social federal state" while mentions that „federation shall be responsible for representing the nation as a whole in capital" (art. 22). It indicates a specific federal feature, namely unity in respect for diversity, autonomy and distinctiveness.

Federalism is one of those concepts difficult to generalize because of the lack of a clear definition, the lack of a uniform schema for federalization process and dynamics of this phenomenon (See: Grzeszczak, 2011). Therefore must be noted that there are as many variants of federal systems as many states and the specifics of each one is determined by the system's 
genesis. There is no difference in relation to Federal Republic of Germany. Federal system is an integral part of the German political tradition. The history of this State is a history of federations or confederations from the Confederation of the Rhine (Rheinbund) starting, German Confederation (Deutscher Bund), German Empire (Deutsches Reich) with 25 constituent States, through the interwar period, the second world war and after 1945

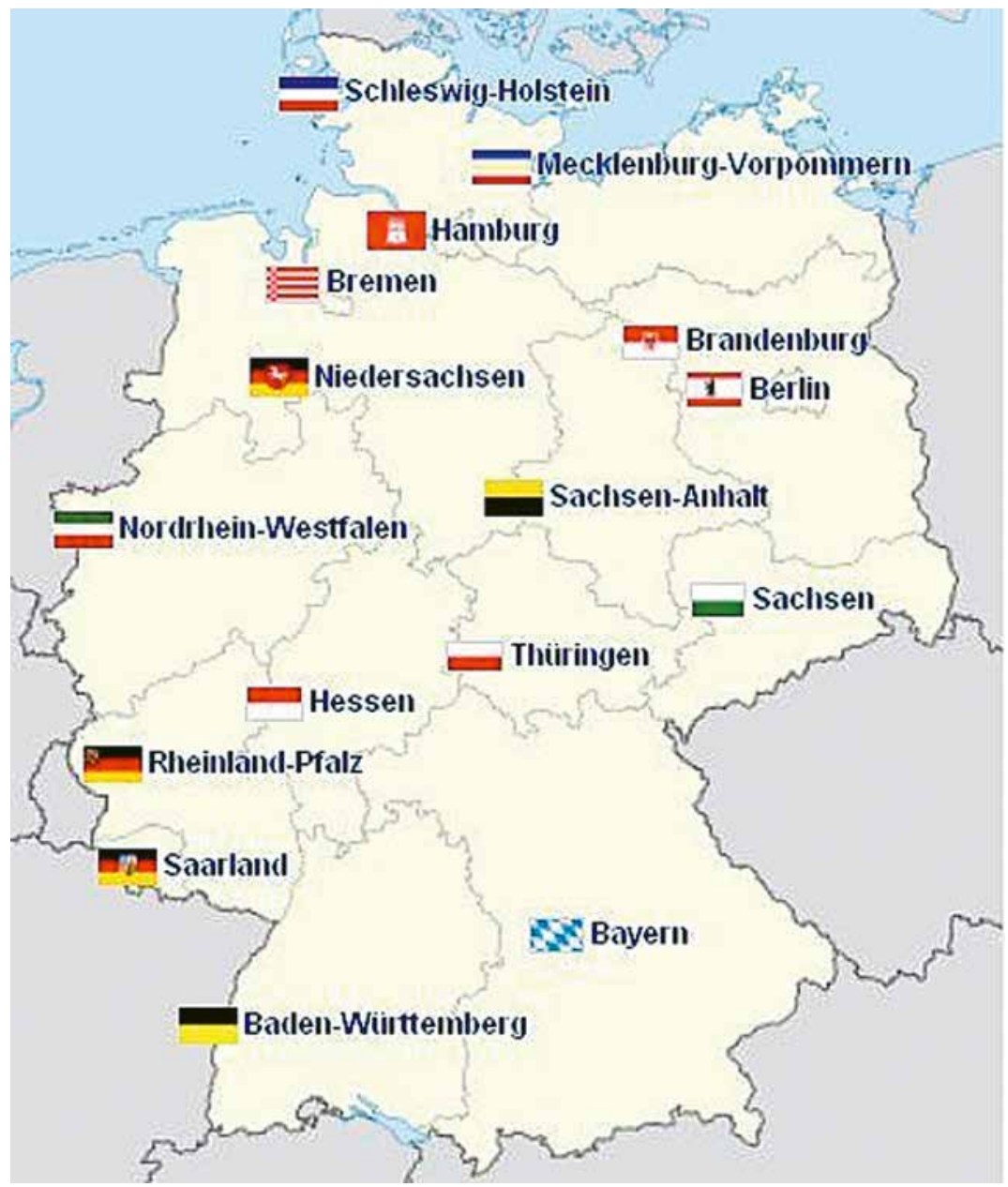

Pic. 1. Federal States ((Bundes)Länder) in the Federal Republic of Germany Source: Landy w Niemczech, n.d. 
(this period particularly affected the shape of the Federation nowadays because of occupation), till today. Therefore, differently than in most of federal states, it was not the way from the centralized state towards federation, a process in which (in order to improve managing of state as a whole) distinctness of different territories are taken into account and granted by freedom to decide on their own affairs, because Germany have never create a unitary state organism (Gdulewicz, 2002, p. 93). The current political system is a continuation of the tradition in the new environment and a confirmation of status quo.

The division on (Bundes)Länder (16) made by the Basic Law had determined the territorial structure of the Federal Republic of Germany (pic. 1).

In its preamble the following Länder have been mentioned: BadenWürttemberg, Bavaria, Berlin, Brandenburg, Bremen, Hamburg, Hesse, Lower Saxony, Mecklenburg-Western Pomerania, North Rhine-Westphalia, Rhineland-Palatinate, Saarland, Saxony, Saxony-Anhalt, Schleswig-Holstein and Thuringia. The three of them have a mixed status combining status of the city and Land. This list seems to be closed, but, as practice showed, (in 1952 the Länder of Baden, Baden-Württemberg and Württemberg - Hohenzollern have merged forming Baden-Württemberg), and lack of provision prohibiting ability to enter changes, the territorial structure, unlike the federal system, is not constitutionally protected.

In accordance with art. 29 of the Basic Law, the territory of the federation, its division, is subject to change provided that „each Land be of a size and capacity to perform its functions effectively". In addition, new delimitation ,shall be given in this connection to regional, historical and cultural ties, economic efficiency, and the requirements of local and regional planning". This may occur through various procedures, through referendum, involving Länder, Bundesrat or Bundestag. Concerned Länder are even entitled to revise the division of their existing territories through the State Treaty, which confirms a quite far - reaching autonomy within the Federation.

The art. 28(1) of the Basic Law states, that Länder have their own constitutional orders, which ",must conform to the principles of a republican, democratic and social state governed by the rule of law (...)", within the meaning of German federal constitution. Therefore, the Länder have been 
granted by legislative rights which are confirmed by the Basic Law in article 70(1) „The Länder shall have the right to legislate insofar as this Basic Law does not confer legislative power on the Federation". Art 70(2) divides competences between the Federation and Länder by distinguishing two categories of legislative powers: exclusive („the Länder shall have power to legislate only when and to the extent that they are expressly authorised to do so by a federal law” - art.71 GG) and concurrent („, the Länder shall have power to legislate so long as and to the extent that the Federation has not exercised its legislative power by enacting a law" - art. 72 GG).

Areas reserved for two above mentioned components of Federal Republic of Germany have been presented in art. 73 (Matters under exclusive legislative power of the Federation) and 74 (matters under concurrent legislative powers). They are also listed in the table 1 below.

Tab. 1. Exclusive and concurrent legislative powers in the Federal Republic of Germany

\begin{tabular}{|c|c|}
\hline $\begin{array}{l}\text { Matters under exclusive legislative power } \\
\text { of the Federation }\end{array}$ & $\begin{array}{r}\text { Matters under con } \\
\text { pow }\end{array}$ \\
\hline $\begin{array}{l}\text { 1. foreign affairs and defence, including } \\
\text { protection of the civilian population; } \\
\text { 2. citizenship in the Federation; } \\
\text { 3. freedom of movement, passports, residen- } \\
\text { cy registration and identity cards, immi- } \\
\text { gration, emigration and extradition; } \\
\text { 4. currency, money and coinage, weights and } \\
\text { measures, and the determination of stan- } \\
\text { dards of time; } \\
\text { 5. the unity of the customs and trading area, } \\
\text { treaties regarding commerce and naviga- } \\
\text { tion, the free movement of goods, and the } \\
\text { exchange of goods and payments with } \\
\text { foreign countries, including customs and } \\
\text { border protection; } \\
\text { 5a. safeguarding German cultural assets } \\
\text { against removal from the country; } \\
\text { 6. air transport; }\end{array}$ & $\begin{array}{l}\text { 1. civil law, criminal law, court organisation } \\
\text { and procedure (except for the correctio- } \\
\text { nal law of pre-trial detention), the legal } \\
\text { profession, notaries, and the provision of } \\
\text { legal advice; } \\
\text { 2. registration of births, deaths and marria- } \\
\text { ges; } \\
\text { 3. the law of association; } \\
\text { 4. the law relating to residence and establi- } \\
\text { shment of foreign nationals; } \\
\text { 4a. (repealed) } \\
\text { 5. (repealed) } \\
\text { 6. matters concerning refugees and expellees; } \\
\text { 7. public welfare (except for the law on } \\
\text { social care homes); } \\
\text { 8. (repealed) } \\
\text { 9. war damage and reparations; } \\
\text { 10. war graves and graves of other victims of } \\
\text { war or despotism; }\end{array}$ \\
\hline
\end{tabular}




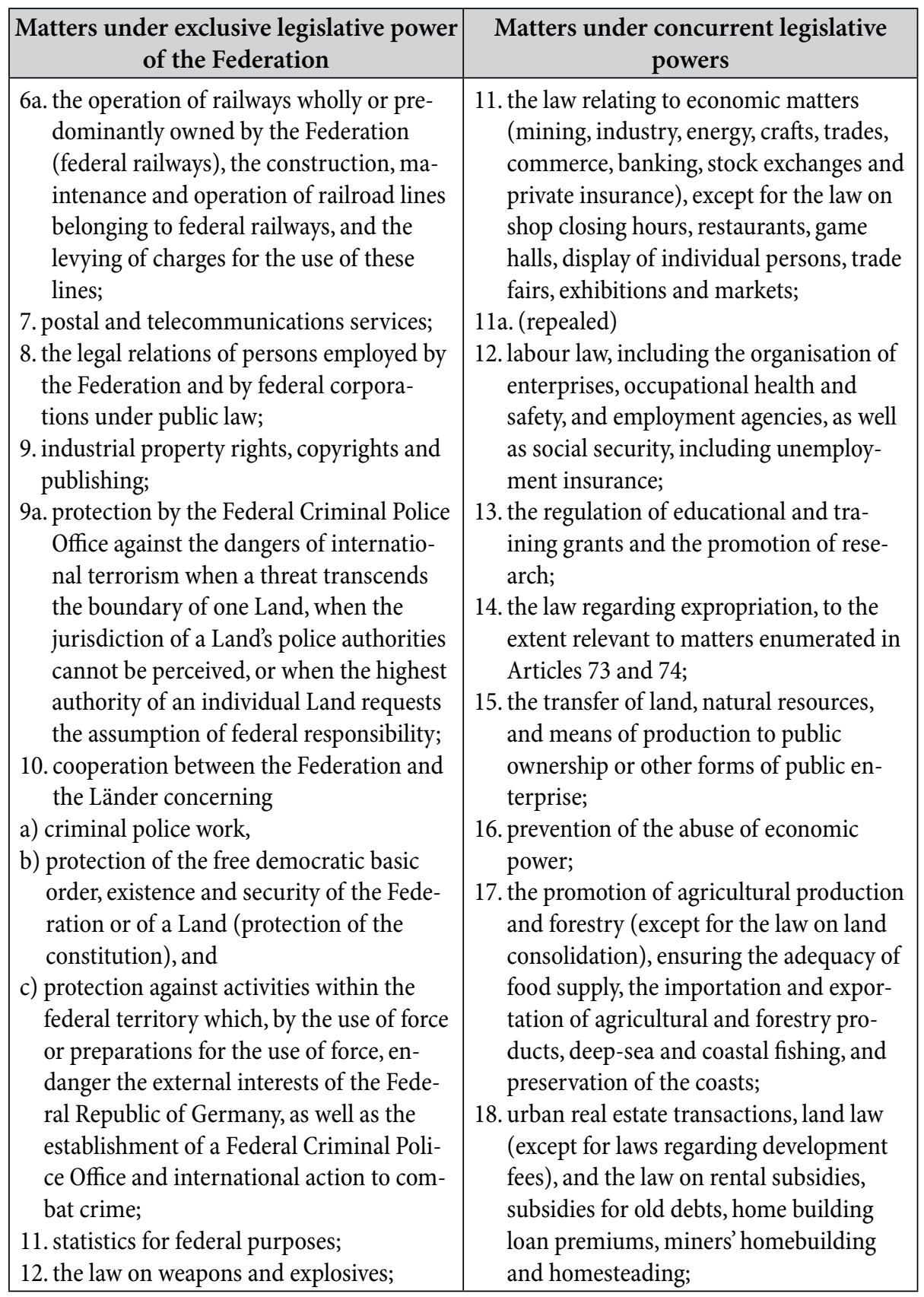




\begin{tabular}{|c|c|}
\hline $\begin{array}{l}\text { Matters under exclusive legislative power } \\
\text { of the Federation }\end{array}$ & $\begin{array}{l}\text { Matters under concurrent legislative } \\
\text { powers }\end{array}$ \\
\hline & $\begin{array}{l}\text { 19. measures to combat human and animal } \\
\text { diseases which pose a danger to the pu- } \\
\text { blic or are communicable, admission to } \\
\text { the medical profession and to ancillary } \\
\text { professions or occupations, as well as the } \\
\text { law on pharmacies, medicines, medical } \\
\text { products, drugs, narcotics and poisons; } \\
\text { 19a. the economic viability of hospitals and } \\
\text { the regulation of hospital charges; } \\
\text { 20. the law on food products including ani- } \\
\text { mals used in their production, the law on } \\
\text { alcohol and tobacco, essential commodi- } \\
\text { ties and feedstuffs as well as protective } \\
\text { measures in connection with the marke- } \\
\text { ting of agricultural and forest seeds and } \\
\text { seedlings, the protection of plants against } \\
\text { diseases and pests, as well as the protec- } \\
\text { tion of animals; } \\
\text { 21. maritime and coastal shipping, as well as } \\
\text { navigational aids, inland navigation, } \\
\text { meteorological services, sea routes, and } \\
\text { inland waterways used for general traffic; } \\
\text { 22. road traffic, motor transport, construc- } \\
\text { tion and maintenance of long-distance } \\
\text { highways, as well as the collection of tolls } \\
\text { for the use of public highways by vehicles } \\
\text { and the allocation of the revenue; } \\
\text { 23. non-federal railways, except mountain } \\
\text { railways; } \\
\text { 24. waste disposal, air pollution control, and } \\
\text { noise abatement (except for the protec- } \\
\text { tion from noise associated with human } \\
\text { activity); } \\
\text { 25. state liability; } \\
\text { 26. medically assisted generation of human } \\
\text { life, analysis and modification of genetic } \\
\text { information as well as the regulation of } \\
\text { organ, tissue and cell transplantation; }\end{array}$ \\
\hline
\end{tabular}




\begin{tabular}{|c|c|}
\hline $\begin{array}{l}\text { Matters under exclusive legislative power } \\
\text { of the Federation }\end{array}$ & $\begin{array}{l}\text { Matters under concurrent legislative } \\
\text { powers }\end{array}$ \\
\hline & $\begin{array}{l}\text { 27. the statutory rights and duties of civil } \\
\text { servants of the Länder, the municipalities } \\
\text { and other corporations of public law as } \\
\text { well as of the judges in the Länder, except } \\
\text { for their career regulations, remunera- } \\
\text { tion and pensions; } \\
\text { 28. hunting; } \\
\text { 29. protection of nature and landscape ma- } \\
\text { nagement; } \\
\text { 30. land distribution; } \\
\text { 31. regional planning; } \\
\text { 32. management of water resources; } \\
\text { 33. admission to institutions of higher edu- } \\
\text { cation and requirements for graduation in } \\
\text { such institutions. }\end{array}$ \\
\hline
\end{tabular}

Source: Own elaboration (based on: The Basic Law, 1949).

Separation of legislative powers on the one hand indicates some organizational arrangements in making-law process by assignment of tasks adequately, point out those of them tnderhe Federation should face with exclusively, because they concern the matters of special importance for the State as a whole. On the other hand, introduces a limitation of federal intervention on matters that Länder can manage on their own. The competitive sphere actually should be considered as the responsibility of Länder, but in case of collision, the primacy is given to Federation. It is presumed that the Federation is able to ensure the implementing of tasks in a more efficient way and has adequate resources and tools to perform them properly.

According to the Basic Law, art. 72 (2), the Federation have the right to legislate on matters of concurrent legislation, „...) falling within clauses $4,7,11,13,15,19 a, 20,22,25$ and 26 of paragraph (1) of Article 74, if and to the extent that the establishment of equivalent living conditions throughout the federal territory or the maintenance of legal or economic unity renders federal regulation necessary in the national interest". Legislative competition should be considered as a positive, because it generally 
boosted effectiveness and efficiency of the legislative process. It cannot be excluded that the Federation will take a large part of legislation over to complete them on its own, but according to article 72(3), even, if the Federation has made use of its power to legislate, „(...) the Länder may enact laws at variance with this legislation with respect to:

1. hunting (except for the law on hunting licenses);

2. protection of nature and landscape management (except for the general principles governing the protection of nature, the law on protection of plant and animal species or the law on protection of marine life);

3. land distribution;

4. regional planning;

5. management of water resources (except for regulations related to materials or facilities);

6. admission to institutions of higher education and requirements for graduation in such institutions".

It should be noted as a quite a large degree of freedom in a law-making considered to be a key area of political activity in each organization. As Tanja Börzel states, the federal system in Germany more than any other appropriately distributes powers between the federal authorities and Länder as federal components. Practically, there is no area where any of the levels would be autonomous in the exercise of legislative powers, because the list of exclusive federal legislative competencies is short and a greater part of tasks is, or can be done both by the Länder and the Federation (Tanja Börzel, 2003, p. 13). It should be noted that federal primacy in area of concurrent legislation leads to some degree of centralization of competencies, and process seems to be supported by the Federal Constitutional Court who has provided a quite broad interpretation of subsidiarity treating it as a political criterion instead as a legal rule (Tanja Börzel, 2003, p. 14).

However, the art. 30 seems to be the most important of constitutional provisions in chapter II of the basic Law (The Federation and the Länder) introducing sovereign powers of the Länder. It states that "Except as otherwise provided or permitted by this Basic Law, the exercise of state powers and the discharge of state functions is a matter for the Länder". By the mentioned above provision the organizational independence of the 
Länder has been confirmed giving them slightly limited but significantly large sovereignty.

Undoubtedly, the Basic Law provides the Länder opportunity to participate in the exercise of power while maintaining a wide extent of autonomy. In order to realise this provision, the Länder, have introduced their own internal organizational solutions: Parliaments (because of their significant participation in the legislative process), executives (governments), judicial authorities, and administration systems. However, in accordance with art. 31, the federal law take the precedence over Land law, therefore, it can be concluded and taking into account, that a rule of supremacy of federal law has been applied.

Within the internal organization of the Länder, next to the requirement of having constitutional order which „(..) must conform to the principles of a republican, democratic and social state governed by the rule of law, within the meaning of the Basic Law", the postulate of representative democracy has been introduced. In each Land, divided into districts and municipalities the people ,shall be represented by a body chosen in general, direct, free, equal and secret elections" (art. 28(1)).

The Länder have been equipped with the right to participate in international relations (art. 32(3)). The Basic Law states: „Insofar as the Länder have power to legislate, they may conclude treaties with foreign states with the consent of the Federal Government" limiting the extent of sovereignty in this area. In certain circumstances, according to art. 24(1a), if „the Länder are competent to exercise state powers and to perform state functions", they may (with the consent of the Federal Government) transfer their sovereign powers to transfrontier institutions in neighbouring regions.

The Federal Republic of Germany is a democratic country with separation of powers. The legislative power is exercised by bicameral Parliament being a representative body for both Federation and Länder, the executive authority is held by the Federal Government with Federal Chancellor and Federal Ministers and finally judiciary system with courts: ordinary, specialized and constitutional. The power comes from the People expressing their will through democratically elected representatives. The head of State is the Federal President holding mainly representative role (Sulowski, Wojtaszczyk, 2005). 
Even though the Federation exercises the power, the Basic Law has introduced a principle of the self - government as a constitutional rule (art. 28). Districts, municipalities and their associations are responsible for managing all local affairs „on their own responsibility, within the limits prescribed by the laws”. Art. 28(2) states also, that „the guarantee of selfgovernment shall extend to the bases of financial autonomy(...)" which include ,the right of municipalities to a source of tax revenues based upon economic ability and the right to establish the rates at which these sources shall be taxed".

There are two other very important principles pointing to the nature of the relations between the central and local authority: the principle of subsidiarity (art. 23) and principle of social state (art. 20). Both of them determine only a secondary role of the State in accordance with both aspects of subsidiarity (limiting of intervention and the obligation to provide assistance) and with positive dimension of restorative justice.

The whole organizational structure theoretically creates a favorable environment for implementation of subsidiarity. The tasks and competencies necessary to perform them have been allocated properly. The Federation deals with matters related to the State as a whole (as a federation of autonomous subunits) and the Länder are highly autonomous in self - governing. Therefore the conditions seem to be the ideal for the postulate of locating all the decision - making processes at possibly the most efficient level or as close as possible to the citizens to materialize, the more that thy have been guaranteed (and protected) by the Basic Law.

\section{PRINCIPLE OF SUBSIDIARITY IN GERMAN LEGAL SYSTEM}

An overview of the German Basic Law's provisions is not, by no means, time - consuming task, but the result brings at least a consternation. The only provision of the German federal constitution, art. 23(1) although refers to the subsidiary directly (expressis verbis) but does so in the context of the European Union. It states: „With a view to establishing a united Europe, the Federal Republic of Germany shall participate in the development of the European Union that is committed to democratic, social and 
federal principles, to the rule of law, and to the principle of subsidiarity, and that guarantees a level of protection of basic rights essentially comparable to that afforded by this Basic Law. To this end the Federation may transfer sovereign powers by a law with the consent of the Bundesrat. The establishment of the European Union, as well as changes in its treaty foundations and comparable regulations that amend or supplement this Basic Law, or make such amendments or supplements possible, shall be subject to paragraphs (2) and (3) of Article 79". This provision authorizes the Federation (with the consent of Länder in Bundesrat) to transfer a part of its sovereignty to the European Union. This reference to the European Union does not seem to be a problem, because the Lisbon Treaty explicitly lists the local actors in Member States as subjects to the effects of the principle of subsidiarity stating: „Under the principle of subsidiarity, in areas which do not fall within its exclusive competence, the Union shall act only if and insofar as the objectives of the proposed action cannot be sufficiently achieved by the Member States, either at central level, or at regional and local level (...)" (Treaty of Lisbon, 2007, art 5.3).

As a result of a deeper analysis of the Basic Law more structures built on the principle of subsidiarity can be identified (Bröhmer, 2014, p. 132). The example is already mentioned article 30 , where the Länder have been entrusted to exercise state powers, perform tasks and the discharge of state functions "Except as otherwise provided or permitted by this Basic Law (...)".

This also applies to legislation (which was mentioned earlier) - art. 70 (1), according to which "The Länder shall have the right to legislate insofar as this Basic Law does not confer legislative power on the Federation". Therefore, there is a presumption of priority of Länder in law - making. According to the principle of subsidiarity this provision limits the scope of State's intervention in the tasks performed within the competencies of federal subunits. At the same time in the provisions regarding the concurrent legislation - art. 72(2), a positive aspect of subsidiarity can be found. Federal authorities are obliged to act in specific areas if required by certain circumstances („The Federation shall have the right to legislate on matters falling within clauses $4,7,11,13,15,19 a, 20,22,25$ and 26 of paragraph (1) of Article 74, if and to the extent that the establishment of equivalent living 
conditions throughout the federal territory or the maintenance of legal or economic unity renders federal regulation necessary in the national interest").

In turn, the art. 72(3) implements the postulate to make decisions as closest to citizens as possible, in areas where the effects of decisions will be affected the most, where some specific circumstances, local determinants need to be taken into account. It is considered as very important, because even if the Federation has made use of its power to legislate in area of concurrent legislation, the Länder are authorized to introduce different regulations in particularly sensitive areas e.g.: protection of nature and landscape management, biological resources particularly in the woods, higher education, spatial planning, land distribution, regional planning, water management.

It is worth to mention also the article 83 respecting the execution of federal laws by the Länder. They are authorized to do this ,in their own right insofar as this Basic Law does not otherwise provide or permit”. Then, in accordance with article 84(1), Länder „shall provide for the establishment of the requisite authorities and regulate their administrative procedures". The Länder can enter their own regulations. Only in "exceptional cases”, when there is , a special need for uniform federal legislation”, the administrative procedure may be regulated by the Federation „with no possibility of separate Land legislation". It should be noted, that such a procedure requires the consent of the Bundesrat.

It is also stated in the same provision that „federal laws may not entrust municipalities and associations of municipalities with any tasks" providing the protection of the local government from federal intervention, which correlates highly with the subsidiarity.

In execution of federal laws the Länder are supervised (in accordance with the law) by the Federal Government (art. 84(3)), which „may send commissioners to the highest Land authorities and, with their consent or, where such consent is refused, with the consent of the Bundesrat, also to subordinate authorities".

Also in financial matters the Federation and the Länder are autonomous and independent of one another (art. 109(1)), although, in order to maintain budgetary discipline and meet „the requirements of overall 
economic equilibrium", they are obliged to perform jointly executing tasks of Federal Republic of Germany arising from its membership in the European Union „pursuant to Article 104 of the Treaty Establishing the European Community" (art. 190(2)). In accordance with art. 190(4), there may be established, by a federal law requiring the consent of the Bundesrat, common rules, applicable to both the Federation and the Länder, on budgetary law management, the responsiveness of budgetary management to economic trends, and long-term financial planning.

Thus, the Basic Law separates powers of the Federation and the Länder. Only when a Land „(...) fails to comply with its obligations under this Basic Law or other federal laws (...)", the so-called federal execution (with the consent of the Bundesrat) may be applied (art. 37). In this case, the Federal Government is authorized to "take the necessary steps to compel the Land to comply with its duties" including the right to issue instructions to all Länder and their authorities (art. 37(2)).

The principle of subsidiarity as a legal and political issue of great importance, has emerged in the European Union as a result of the pressure from the German Länder (Dams, Heide, 1995, p. 945) concerned about the growing participation of the EU's institutions in exercising of powers and performing tasks in areas, where the internal legislation of the Member States were exercised rather by its sub-units than the central authorities. Therefore, they have sought to create some mechanisms that would be useful in monitoring and control of this kind of tendencies (Burrows, Carter, Scott, 2004). In Germany the principle of subsidiarity had been implemented much earlier than in the EU and has been proven in practice offering - within the federal system - an optimal balance between the State and local authorities (Calabresi, Bickford, 2014, p. 134-135), that is why it has been proposed to the European Union (Weinberger, 2014, p. 49).

The principle of subsidiarity in the Federal Republic of Germany is included in a legal act of the highest rank - The Basic Law, which provides its implementing. The Länder and local authorities exercise most of the functions of the State and their autonomous sphere is constitutionally protected by the introduction of subsidiarity, even with regard to the European Union. Due to the fact, that the Basic Law is an general act, 
further manifestations of subsidiarity can be found in the lower - order legislation, mainly those regarding local government.

\section{A SHORT OVERVIEW ON CHARACTERISTICS OF THE LOCAL GOVERNMENT IN GERMANY}

As previously mentioned, the subsidiarity explicitly is expressed in localism, local government, therefore it is worth to analyse the structure of local administration in the Federal Republic of Germany.

The Basic Law, regulating mainly the relations between the Federation and the Länder, only occasionally mentions on local government e.g., in art. 28(1), ordering, that in Länder, districts and municipalities the people be represented by a body chosen in five - adjectives (general, direct, free, equal and anonymous) election or in art. 84(1) - the last sentence - excluding possibility to entrust municipalities and associations of municipalities with any tasks by federal law.

Undoubtedly, the local government is separated from the Federation being associated with the Land. It is, according to H. Wollmann, S. Kuhlmann (2008) "institutionally related" to organizational structure of the Land. Within the frame of the Land internal structure of local government is highly diversified, which reflects internal heterogeneity of the Federal Republic of Germany resulting from the division of the State into the occupation zones after the second World War (Edwards, Meer, 2000, p. 99).

In German political system local authority bodies or local public administration (German Kommunale Selbstverwaltung) consists of municipalities (Gemeinden), districts (Kreise) and district-free cities (Kreisfreie Städte). Each Land has its own administrative structure which organization and functioning is determined in the communal and district laws.

The basic unit of local administration is municipality. There is a local council as a representative organisational body electing directly by local population in each of them (according to article 28(1) of the Basic Law). The are many different committees playing significant role in their functioning. It is also common enabling people who are not related to public administration to taking part in committees' activity if they have 
knowledge or skills which can be useful in decision-making process at local level (professionalism) (Grzeszczak, 2006, p. 14). These are only common characteristics of German municipalities. They differ on their nature (rural, urban), and this character highly determines their organizational structure, tasks, powers, the way they execute them. The differences are also noticed in the length of the term of office of the local council and number of councillors, but the most significant are distinctiveness's regarding the executive body - mayor (or so-called (city) director), particularly its election, responsibilities and relations to the local council.

Despite the above mentioned differences, some patterns can be observed enabling to distinguish four models of local government in Germany (tab. 2):

1. the northern - German model (Norddeutsche Ratverfassung);

2. the southern - German model (Süddeutsche Ratverfassung);

3. The Mayoral system (Bürgermeistererfassung);

4. The Municipal (town hall or collective) model (Magistratverfassung) (Edwards, Meer, 2000, p. 96).

In the Länder in the former German Democratic Republic completely different system of local government was established. Because of strong centralization local government lost its basic competences and could not be implied in the new reality after the unification. That is why in vast majority of them the South - German model has been applied (Edwards, Meer, 2000, p. 96).

The Northern - German model is called English, the South - German Bavarian, the Mayoral model is Rhenish or French and Municipal Prussian (Kardas, Kucharska, 2011, p. 95, 96). It should be noted, that the first one and the last one are of historical only importance as they cannot be found in their original form (Grzeszczak, 2006, p. 14).

The Northern - German model is structurally related to English local government system. It was implemented in this part of Germany occupied by the United Kingdom after the Second World War - in the North RheineWestphalia and the Lower Saxony. The influence of the Anglo - Saxon tradition making a strict separation between politics and administration can be easily noticed (Edwards, Meer, 2000, p. 97). In this model the main body is the local council with the mayor (der Bürgermeister) as a chair- 
man, but at the same time there is another one - the city director, manager (Stadtdirektor), chief executive official, a head of the local civil service. The city director can be compared with English „town clerk”, city manager, while the Bürgermeister with English mayor (Grzeszczak, 2006, p. 150. Both of them were elected by the local council which made their legitimacy to exercise power more weak. In the end of the twentieth century the North - German model was rearranged in accordance to the South - German model introducing some modifications, e.g. the direct election system for mayor heading (optionally) the local council.

In the Municipal system two bodies are authorized to exercise powers: the local council and magistrat (council of aldermen, German Beigeordnete) as an executive body. The model, as original introduced direct election system for the local council and indirect for the mayor and members of Magistrat. The typical for local governments' hierarchical relationship between the aldermen and the mayor does not exist. They form a kind of college instead where the mayor heading the council of aldermen, is regarded as a first among equal - "primus inter pares" (Edwards, Meer, 2000 , p. 97). His position (weak due to its legitimacy derived from indirect election) were weakened by depriving the mayor of the opportunity to perform the function of the local council's chairman. The council preferred to

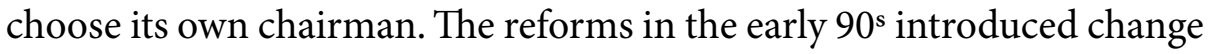
strengthening the position of mayor. Currently it is elected directly by local population. The modified model can be found in Hesse, cities of the Schleswig - Holstein and Bremenhaven belonging to Brema with mixed status of the Land and the city.

The Mayoral system is characterized by the presence, next to the local council and the mayor, also additional mayors elected indirectly - by the local council. This model grants quite large range of powers to the mayor making him/her a head of the local council and giving the possibility to perform responsibilities independently of the local council (as a head of municipal administration) at the same time. The system originally was applied in Rhineland-Palatinate, Saarland, and rural municipalities of Schleswig - Holstein. Nowadays, although in a modified form, with the directly elected mayor, practically is approaching to the southern - German model. 
Definitely the most prevalent in the organization of local government in Germany is the southern German model considered to be the most optimal and therefore accepted by most Länder (even if previously they had operated within a different model) and adopted in its entirety or with modifications. It offers a balanced relation between the local council and a mayor - both elected directly. The mayor's position is very strong. He (or she), elected by the population, is a head of the local council, all local committees, the executive body, the head of local administration and its official representative. In practice, the mayor is the most important institutional body in municipal administrative structure. The local council is not authorized to dismiss the mayor and the latter cannot call new elections for the local council (Edwards, Meer, 2000, p. 98). The southern German system is referred as the dualistic model "local council - mayor" under a single authority (Grzeszczak, 2006, p. 200. In its original form can be found in Bavaria, Baden-Württemberg and Saxony. The Länder such as Brandenburg, Mecklenburg - Western Pomerania, Saxony-Anhalt, Schleswig-Holstein and Lower Saxony have introduced some modifications separating the function of mayor and the chairman of the local council in order to protect the control powers of the local council as a legislative body. Only the rules of Lower Saxony enables the local council to elect the mayor as its chairman. The model is respectively called a dualistic "local council - mayor" under two authorities.

Tab. 2. Organizational characteristics of municipalities in the Federal Republic of Germany

\begin{tabular}{|l|l|l|}
\hline \multicolumn{1}{|c|}{ MODEL } & \multicolumn{1}{|c|}{ LAND } & \multicolumn{1}{c|}{ CHARACTERISTICS } \\
\hline $\begin{array}{l}\text { Municipal } \\
\text { (Prussian) }\end{array}$ & $\begin{array}{l}\text { Hesse } \\
\text { Schleswig-Holstein } \\
\text { Brema } \\
\text { Hamburg } \\
\text { Berlin }\end{array}$ & $\begin{array}{l}\text { Two institutional bodies: local council and the mayor } \\
\text { Separated competences } \\
\text { The mayor elected by the local council } \\
\text { The mayor and aldermen are equal but the mayor is } \\
\text { primus inter pares” }\end{array}$ \\
\hline $\begin{array}{l}\text { Northern } \\
\text { German } \\
\text { English) }\end{array}$ & $\begin{array}{l}\text { Lower Saxony } \\
\text { North Rhine-Westpha- } \\
\text { lia }\end{array}$ & $\begin{array}{l}\text { Main institutional body - the local council } \\
\text { the mayor elected by the local council } \\
\text { the mayor heads the local council } \\
\text { The city Director, manager as another body leads the } \\
\text { administration, elected by the local council }\end{array}$ \\
\hline
\end{tabular}




\begin{tabular}{|l|l|l|}
\hline \multicolumn{1}{|c|}{ MODEL } & \multicolumn{1}{|c|}{ LAND } & \multicolumn{1}{c|}{ CHARACTERISTICS } \\
\hline $\begin{array}{l}\text { Southern } \\
\text { German } \\
\text { (Bavarian) }\end{array}$ & $\begin{array}{l}\text { Bavaria } \\
\text { Baden-Württemberg } \\
\text { Saxony }\end{array}$ & $\begin{array}{l}\text { Decision - making powers divided between the local } \\
\text { council and the mayor } \\
\text { bodies elected directly } \\
\text { the mayor chairs the local council }\end{array}$ \\
\hline $\begin{array}{l}\text { Mayoral } \\
\text { (Rhenish or } \\
\text { French) }\end{array}$ & $\begin{array}{l}\text { Saarland } \\
\text { Rhineland-Palatinate }\end{array}$ & $\begin{array}{l}\text { Local council and the mayor elected by the local co- } \\
\text { uncil } \\
\text { Bodies elected directly } \\
\text { Additional mayors elected indirectly }\end{array}$ \\
\hline
\end{tabular}

Source: own elaboration (based on Kardas, Kucharska 2011, p. 95-96).

In the German two-tier local structure municipalities are considered to be local government's institutions in the strict sense, but there are districts (Landkreise) at the supra - local level treated as territorial corporations or associations of municipalities. There are only three exceptions - in the cities - Länder (Berlin, Hamburg, Brema) the absence of districts is noticed. Usually, according to law, cities with a population of over one hundred are excluded from existing districts and become autonomous, district - free cities.

Unlike German municipalities districts form quite homogeneous organizational system. The details have been determined in district laws (Landkreisordnungen) different in each Land.

The legislative power in districts is performed by directly elected district council (Kreistag). Its term of office usually lasts for 5 years (there are only three exception to this rule - Bavaria where the district council is elected every 6 years, Hesse and Schleswig - Holstein every 4 years). The district council is exclusively authorized to manage budgetary matters and establish the local law.

The executive body in district is a district governor - Landrat (male)/ Landrätin (female), elected either by the district council or by population in general election. The Landrat has a great number of responsibilities, practically a whole activity of the district administration. It includes not only executing of the local law made by the district council but also, what is significant, performing tasks entrusted to district by the state administration. 
In the Länder of Lower Saxony, North Rhine - Westphalia, Saarland, Brandenburg Mecklenburg - Western Pomerania there is the third institutional body called „district committee” (Kreisausschuss).

In the organizational structure of districts in the Federal Republic of Germany some basic models can be distinguished:

1. the south German model (süddeutsche Kreistagsverfassung);

2. the district committee model (Kreisausschussverfassung)

3. (in the older literature) the directorial model (Direktorialverfassung) with the district director instead of the Landrat (tab.3).

Tab. 3. Organizational models of districts in the Federal Republic of Germany

\begin{tabular}{|l|l|}
\hline \multicolumn{1}{|c|}{ MODEL } & \multicolumn{1}{c|}{ THE LÄNDER } \\
\hline Southern German & $\begin{array}{l}\text { Bavaria } \\
\text { Baden-Württemberg, } \\
\text { Rhineland-Palatinate, } \\
\text { Saxony } \\
\text { Saxony-Anhalt } \\
\text { Thuringia } \\
\text { Saarland }\end{array}$ \\
\hline District Committee & $\begin{array}{l}\text { Brandenburg } \\
\text { Mecklenburg-Western Pomerania, } \\
\text { Lower Saxony } \\
\text { North Rhine-Westphalia }\end{array}$ \\
\hline Directorial & $\begin{array}{l}\text { North Rhine-Westphalia } \\
\text { Lower Saxony }\end{array}$ \\
\hline
\end{tabular}

Source: own elaboration (based on Grzeszczak, 2006).

The southern German model can be described as dualistic with relatively strong position of the district governor elected (except the Baden Württemberg) directly. He/she leads the district council, district committees, heads the district administration and represents district in external relations.

The Landrat's position in the district committee system is much more weaker. The district committee's competences are wide in extent, and the Landrat executes both the decisions of the district council and district committee. In addition he/she chairs the district administration. 
Particularly interesting solution can be found in Bavaria, where at the district level the state and local administration organizational, personal and in respect of assets are closely associated.

The analysis of the German local administration structure, even general, confirms a large extent of the organizational autonomy of local government creating a very convenient environment to implement the principle of subsidiarity. It should be noted that at the local level there is a dualism of administration system. It is clearly visible in functioning of districts and district - free cities, which perform a lot of tasks delegated by the state administration. There is also noted an institutional integration of the local and state administration. As a result, the districts are the lowest tier in the hierarchy of state administration which, at least formally, acts separately from the local government (Wollmann, Kuhlmann, 2008). Only municipalities can be considered as elements strictly related to local government structure.

Not only an organizational structure contributes can be found among the determinants of implementing of the principle of subsidiarity. It is also important to take into account tasks and competences to perform them. The Basic Law's provisions concern only the matters between the federation and the Länder. It is forbidden to use federal laws to entrust municipalities and their associations with any tasks. Therefore, there is no State's intervention in this area. The local government institutionally is related to the Land. Similar to relations between the Federation and Land, where the Lander are autonomous in creating their own administrative structure within which they perform certain tasks, they also refrain from intervening in local internal affairs. Too many tasks delegated and developing the supervising institutional structure would be in the opposite to logics of the self-government turning this administrative level into the State territorial agencies. Therefore, the negative aspect of subsidiarity can be observed here. Higher administrative levels are only of secondary, assistant role in relations to those the closest to citizens.

It can be said that the legislation has been centralized at the federal level, the administration and implementation of laws are highly autonomous. It enabling the public administration to cooperate widely by performing tasks not only between units at the same levels but also between different 
tiers. This cooperation is permanently developing, because it is voluntary action, bringing many benefits, boosting efficiency, effectiveness, confirming local creativity, unlike a compulsory intervention considered as a result of the local authority's impotence.

It should be noted that the range of the duties and responsibilities discharged to local authorities in Germany is unusually broad. Local governments have been entrusted a growing number of tasks permanently extended for the last decades. This applies particularly to health policy, public welfare, public housing and environment protection, which should be managed locally, close to the citizens, as the specific needs and possibilities to meet them are known the best at this level. Most of the tasks previously were the Länder responsibilities. Nowadays the main functions of the German local government are considered to be in the field of welfare policy (child and youth care, old and disable people), public housing and building policies, urban planning, public transport and environment protection.

German local government can be seen as a multifunctional with an enormous number of tasks resulting not only from the needs of local communities but also from legal requirement to implement laws made at the higher tiers of administration, including those resulting from membership in the European Union. H. Wollmann i S. Kuhlmann estimated that approximately $70-85 \%$ of the above mentioned legislation is implemented by local governments (Wollmann, Kuhlmann, 2008).

It is significant that the administrative autonomy of German local government and a vast number of tasks, has opened $\mathrm{w}$ way to cooperate with non - administrative entities (the third sector). As a result a lot of responsibilities have been discharged to non - government organizations implementing the subsidiarity in horizontal aspect of the rule. Local government is considered to be only of secondary, assisting (mainly financially and by deliver a legal support) role, a partner of social organizations in all those areas of the local communities life. 


\section{CONCLUSIONS}

The German organizational structure is a very convenient environment to implement the principle of subsidiarity. The best performing circumstances include at least a tendency to distribute powers in order to execute them independently and there is some level of integration within this autonomy at the same time. The federal system in the Federal Republic of Germany systems meets those requirements. It should be noted, that not all federal systems give a priority to execute powers at the possible lowest level. In addition, it is important to divide competences in the legal act located at the top of hierarchy in the legal system (usually in the Basic Law). All those requirements are fulfilled in Germany, the principle of subsidiarity has been included in the Basic Law and although it refers mainly to the European Union, taking into account further constitutional provisions and fact that the Treaty of Lisbon considers all local communities as elements of the system in which the subsidiarity should be realised, it can be - with no doubt - practically implemented.

The Basic Law divides competences between the Federation and the Länder. With slightly limited sovereignty The Länder are authorized to make decisions autonomously in all areas of their activity, starting from the legislation, judiciary system, executing law till establishing their own administrative system. Within the organizational structure of the Länder German districts and municipalities can be found. Although they are institutionally related, those relations reflected those between the federation and the Länder. The organizational freedom concerning the structure of districts and municipalities has resulted with different models of their functioning.

There is a particular attention paid to the negative aspect of subsidiarity in academic discussion. In the Federal Republic of Germany it can be notes instantly. The legislation, divided between the Federation and the Länder separate local government from them by forbidding using the federal law discharging tasks. Therefore, the postulate the upper levels to refrain from intervene without any reason can be realized. To the Federation and the Länder only secondary role has been given. A whole of the public tasks are a responsibility of the lowest tiers of the administration. As about 
the positive aspect of the principle of subsidiarity, it seems to be more expressed by the cooperation of the entities regardless of the administrative level than by the intervention. The tasks delegating in different directions (vertical and horizontal, sharing or cooperating in tasks performing is not problematic, it is even considered to be an important element of political culture. It is worth to note that it is not limited to the public administration. The vertical autonomy of local government discharged by a vast number of responsibilities expected to be done effectively, in natural way implies a freedom of cooperation with non - governmental entities. With financial and legal support they are able to perform tasks better. Therefore, the implementation of subsidiarity in its vertical (political) dimension makes possible to introduce its horizontal aspect binding closely, within the territorial communities, two usually separated spheres: the administration and the society.

\section{BIBLIOGRAPHY}

Bednar, J. (2014). Subsidiarity and robustness: building the adaptive efficiency of federal systems. Nomos LV NY Press.

Blank, Y. (2009). Federalism, subsidiarity and the role of local governments in an age of global multilevel governance. Fordham Urban Law Journal, 37.

Boka, E. (2014). Rethinking the role of the federalist ideas in the construction of Europe. Retrieved from http://eva-boka.wdfiles.com/local-files/start/ RethinkingTheRole.pdf

Börzel. T. (2003). Subsidiarity and the constitutional premise for regional government in Europe. Retrieved from http://userpge.fu-berlin.de/ europe/ forschung/docs/boerzel_2003.pdf

Bröhmer, J. (2014). Subsidiarity and the German Constitution in Global Perspectives on subsidiarity. Ius Gentum: Comparative Perspectives on Law and Justice, 37.

Burrows, N., Carter, C., Scott, A. (2004). Subsidiarity and the draft treaty, prepared for sub rosa discussion Brussels. Retrieved from www.regleg.eu/doenloads/ activities/9.doc 
Calabresi, S.G., Bickford, L.D. (2014). Federalism and subsidiarity. Perspectives from US constitutional law. In J.E., Fleming, J.T., Levy (Eds.), Federalism and subsidiarity. Nomos LV NY Press.

Chmielewska, L. (2012). Johannes Althusius - pierwszy teoretyk federalizmu. Doctrina, 1. Retrieved from www.doctrina.uph,.edu.pl/doctrina_2012/1_1_ Chmielewska\%20Lucyna\%20Doctrina\%202012.pdf

Dams, T., Heide, H.J.v. (1995). Subsidiaritätsprinzip. In: Akademie für Raumforschung und Landesplanung (Eds.) Handwörterbuch der Raumordnung. Hannover: ARL.

Demirci. B. (2003). The principle of subsidiarity in the European union context. School of Social Sciences of Middle East Technical University.

Drèze J. (2009). On the interaction between subsidiarity and interpersonal solidarity, Re-bel ebook. Retrieved from http://www.rethinkingbelgium.eu/rebelinitiative-files/ebooks/ebook-1/Re-Bel-e-book-1.pdf

Edwards, A., Meer, J. vd (2000). Germany: administration meets community. In H. Daemen, L Scaap (Eds.) Citizens and city; developments in fifteen local democracies. Delft Eburon.

Endo (2001). Subsidiarity and its enemies: To what extent is sovereignty contested in the mixed commonwealth of Europe? Fiesolana: European University Institute. Endo, K. (1994). The Principle of Subsidiarity: From Johannes Althusius to Jacques Delors. Hokkaido Law Review, 44(6), p. 652-553. Retrieved from http://hdl.handle.net/2115/15558

Gdulewicz, E. (2002). Ustrój polityczny Niemiec. In Skrzydło W. (Ed.), Ustroje państw współczesnych (Vol. 1). Lublin.

Gierycz, M. (2009). Zasada pomocniczości w Traktacie z Lizbony. Źródła i znaczenie modyfikacji. In M.M. Brzezińska, R. Zenderowski (Eds.), Traktat lizboński. Co po Irlandii? Warszawa: Uniwersytet Kardynała Stefana Wyszyńskiego w Warszawie.

Grzeszczak, R. (2006). Struktura administracji w Niemczech. Wrocław: Uniwersytet Wrocławski.

Grzeszczak, R. (2011). Federalizm - ustrój Niemiec i (czy?) Unii Europejskiej, Nowa politologia. Retrieved from https://www.nowapolitologia.pl/politologia/ europeistyka/federalizm-ustrój-niemiec-i-czy-unii-europejskiej 
Kardas, M. Kucharska, C. (2011). Analiza porównawcza modeli samorządu terytorialnego Niemiec, Wielkiej Brytanii i Szwecji. Akademia Marynarki Wojennej w Gdyni, Colloquium Wydziału Nauk Humanistycznych i Społecznych, 3.

Landy w Niemczech (2014). Retrieved from http://www.deutschkurs.pl

Martin, A. (2010). The principle of subsidiarity and institutional predisposition: Do the European Parliament, the German Bundestag and the Bavarian Landtag define subsidiarity differently?. July 2010 Research Group On European Affairs CAP Working Paper.

Pållson, A.-M. (2013). The European Unions' principle of subsidiarity an empty promise. Bruxelles: EUD an alliance for a Europe of democracies Bruxelles.

Schout, A., Wolff, S. (2010). Ever closer union? Supranationalism and intergovernmentalism as concept. $5^{\text {th }}$ Pan-European Conference on EU Politics, Porto Portugal 23-26 June 2010 „How EU institutions form positions”. Retrieved from http://www.jhubc.it/ecpr-porto/virtualpaperroom/086.pdf

Spiering, R. Albrecht, N. (1990). Politik auf einen Blick, Buch und Zeit Verlangsgesellshaft, Köln.

Sulkowski, S., Wojtaszczyk, K.A. (Eds.) (2005). System polityczny Republiki Federalnej Niemiec. Warszawa: Dom Wydawniczy Elipsa.

Swenden, W. (2006). Federalism and regionalism in Western Europe. A comparative and thematic analysis. Macmillian Palgrave.

The Basic Law of the Federal Republic of Germany (1949). The Library of Seym. Retrieved from http://libr.sejm.gov.pl/tek01/txt/konst/niemcy.html Treaty of Lisbon (TL) (2007). Dziennik Urzędowy Unii Europejskiej, C 306/01. Treaty of the European Union - TEU (2004). Dziennik Ustaw, 90, poz. 864/5.

Watts D. (2003). Understanding US/UK government and politics. A comparative guide. Manchester University Press.

Weinberger, L.D. (2014). The relations between sphere sovereignty and subsidiarity. Ius Gentum: Comparative Perspectives on Law and Justice 37.

Wollmann, H., Kuhlmann, S. (2008). UCLG Profiles: Germany. Retrieved from http://www.cities-localgovernments.org/gold/Upload.country_profile/Ger many.pdf

Wyatt, D. (2003), Could a "yellow card" for national parliaments strengthen judicial as well as political policing of subsidiarity?. Retrieved from http://idpbarcelona. net/docs/recerca/dtetue/docs/pdf/subsid_workinpapers/wyatt_8.pdf 